\title{
Evaluation of Fluted Pumpkin (Telfairia occidentalis, Hook f.) Waste as Nutrient Amendment in Compost for its Effective Management and Crop Production.
}

\author{
A.A. Soyingbe ${ }^{1}$, T. B. Hammed ${ }^{2}$, C.O. Rosiji ${ }^{1}$, and J. K. Adeyemi ${ }^{1}$ \\ ${ }^{I}$ Department of the Environmental Health Sciences, Ogun State College of Health Technology, Ilese, Ijebu, \\ Nigeria. \\ ${ }^{2}$ Department of Environmental Health Sciences, Faculty of Public Health, College of Medicine, University of \\ Ibadan, Nigeria
}

\begin{abstract}
The study investigated the Telfairia occidentalis waste (leaves and stalk) potential in supplementing the naturally low nutrients in compost. Experimental study design was conducted inside windrows to compare different recipes for aerobic composting of the waste. Total of four windrow chambers (labeled as: $\boldsymbol{A A}, \boldsymbol{B B}, \boldsymbol{C C}$, TO) were used. Inside each chamber, compost recipes were varied viz: AA contained mixture of Telfairia occidentalis waste, Cow Intestinal Waste (CIW) and other organic waste from Mixed Municipal Waste (MMW); BB contained Telfairia occidentalis waste and CIW; CC contained CIW and MMW; and, TO contained Telfairia occidentalis waste alone. The ratio of 3:1 was maintained for either Telfairia occidentalis waste or $M M W$ and cow waste respectively. The materials were allowed to decompose for a period of 12 weeks. At maturity composts samples were analyzed for their nutrient and heavy metal compositions. BB appeared to be the best recipe for Telfairia occidentalis waste management through composting. It gave the highest values for the following nutrients: $C(37.350 \pm 0.212 \%), N(3.205 \pm 0.007 \%), P(1.310 \pm 0.028 \%), M g(0.500 \pm 0.057 \%)$, and $\mathrm{Ca}(0.730 \pm 0.028 \%)$ that are of good compost characteristics. The levels of nutrients and heavy metals were within the ranges of national and international standards. Hence, the management of Telfairia occidentalis waste through composting serves dual purposes of recovering nutrients locked-up in the stalk and leaves for plant growth and environmental sanitation.
\end{abstract}

Keywords - Composting, Environmental sanitation, Fluted pumpkin, Plant growth, Waste management

\section{Introduction}

Fluted pumpkin (Telfairia occidentalis Hook f.) is widely recognized for its nutritional and medicinal uses across the six geo-political zones in Nigeria. Previous studies usually focused on how to improve its cultivation [1-6], increase its yield [7,8] and use it in controlling pests or nutritional purposes [9-11]. Little information is available on management of its waste after consumption, perhaps through composting. Once the pumpkin leaves and seeds are removed for various uses, the remaining recalcitrant stalks and leaves are thrown into refuse bin, open dumps (Plate 1) or ends up in a flowing stream. This practice can have serious implications on environment and health. In Nigeria, the rich diversity of the Indigenous Leave Vegetables (ILVs), including Telfairia occidentalis had earlier been documented by several researchers [12-14]. Twoseason field trials were conducted between 2004 and 2006 [11] to evaluate the effect of intercropping Telfairia occidentalis cv.EN2000-25 with okra cv. NHAe47-4 and pepper NHV1A on the populations of nematode pests of these vegetables. This study showed that using resistant/tolerant varieties as component crop in Telfairia production could be a useful approach in root-knot nematode management. Also, in order to improve fluted pumpkin production in Nigeria, Asoegwu [1] compared irrigation frequencies of 3, 6 and 9 days intervals with no irrigation. It was found out that irrigation prolonged the productive life of the crop and enhanced leaf and pod yields. In a similar study, biochemical composition of fluted pumpkin at different stages of growth was determined [15]. The study suggested that young leaves be properly cooked in order to remove anti-nutrient effects before consumption.

In terms of its nutritional potentials, freshly harvested T. occidentalis matured leaves were processed and analyzed on the basis of supplementing diets in broiler starter [16]. The leaves were remarkably high in crude protein. In the recent time, fluted pumpkin had gained medicinal recognition. It has been discovered to be blood purifiers [5]. Also, the leaf had a high nutritional, medicinal and industrial values being rich in protein (29\%), fat (18\%), minerals and vitamins (20\%) [17]. It has been reportedly used by ethno medicinal practitioners to treat anaemia [6], convulsion [18], heart diseases, hypertension, hypoglycemia, diabetes and even in fatal cases of meningitis [19]. Also, the responses of fluted pumpkin seeds to chilling and hydrated storage at 6,16 , and $25^{\circ} \mathrm{C}$, and excised axes to fast flash-drying or slow dehydration were investigated [20]. 
The results revealed that fluted pumpkin seeds were recalcitrant; being both desiccation- and chilling-sensitive. It was concluded that short-term storage in the hydrated state appeared to be unachievable in practice.

Earlier on, discussions were held on biotechnological applications such as meristem culture, in vitro selection, zygotic embryo culture, somatic embryo genesis, protoplast culture, anther culture and genetic engineering that could solve production problems associated with some selected ILVs [4]. Akoroda carried out studies during 1980-1987 to raise seed production of the fluted pumpkin [7]. Akanbi and others explored the use of composts in form of foliar spray or liquid fertilizer as nutrient source and botanical insecticide on Telfairia occidentalis crop [5]. The findings suggested a dual role of this compost extract foliar sprays as source of nutrients and materials for controlling insect pests. Despite all these research efforts on how to improve the production of fluted pumpkin and their various uses, the use of fluted pumpkin wastes as source of nutrients to crop have not been fully exploited in Nigeria. The present study investigated the pumpkin potential in supplementing the naturally low nutrients of compost or organic fertilizer, with a view of improving its waste management and food security in the country.

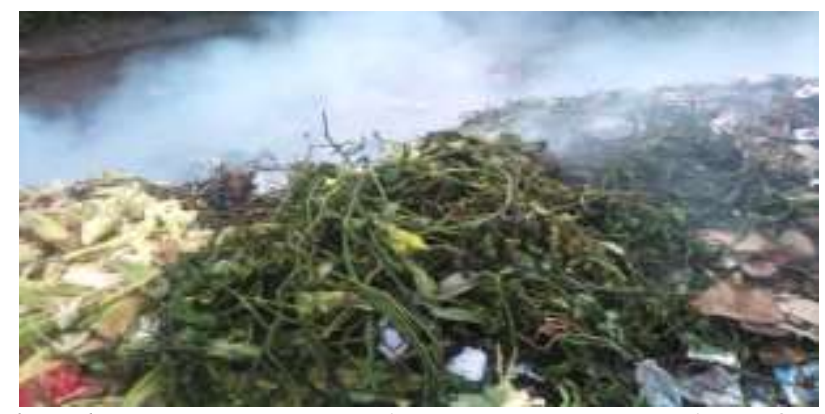

Plate 1. Telfairia occidentalis waste been burnt in an open dump beside a flowing stream in Ibadan (Picture by Hammed T. B., 2012)

\section{Methodology}

Experimental study design was conducted inside windrows to compare different recipes for aerobic composting of Telfairia occidentalis waste (leaves and stalk). Total of four windrow chambers (labeled as: AA, $\mathrm{BB}, \mathrm{CC}, \mathrm{TO}$ ) were used. Inside each chamber, composting recipes were varied viz:

AA contained mixture of Telfairia occidentalis waste, Cow Intestinal Waste (CIW) and other organic waste from Mixed Municipal Waste (MMW);

BB contained Telfairia occidentalis waste and CIW;

CC contained CIW and MMW;

TO contained Telfairia occidentalis waste alone.

Hence, CC without Telfairia occidentalis waste served as control. The ratio of 3:1 was maintained for either Telfairia occidentalis waste or MMW and cow waste respectively. The materials were allowed to decompose for a period of 12 weeks. Composting was monitored in the windrow chambers through the use of specified tools and direct observation as described in a previous study [21, 22]. At maturity composts was stored for a further period of 2 weeks for complete stabilization. After natural drying in the sun and sieving to remove non-biodegradables such as plastics, metals, gravel, composite samples were taken for chemical analysis. Organic-carbon, total nitrogen, total phosphorus, magnesium, potassium, calcium, sulphur, iron, lead, chromium, nickel, zinc, and cadmium contents were analyzed.

Determination of lead $(\mathrm{Pb})$, chromium $(\mathrm{Cr})$, nickel $(\mathrm{Ni})$, zinc $(\mathrm{Zn})$, and cadmium $(\mathrm{Cd})$ in the compost samples was done by weighing $1 \mathrm{~g}$ of ground sample into a conical flask. To this, $5 \mathrm{ml}$ of digestion reagent (2:1 conc $\mathrm{HNO}_{3}$ : conc $\mathrm{H}_{2} \mathrm{SO}_{4}$ ) were added and heated until brown peroxide and white perchloric acid evaporated. The resulting residue was dried. The procedure was repeated until a white precipitate remained in the flask. This was then filtered through a Whatman filter paper No 1 into a $100 \mathrm{ml}$ volumetric flask. The filtrate was diluted with $0.1 \mathrm{~N} \mathrm{HNO}_{3}$ (p.a) to $100 \mathrm{ml}$. The digested samples were then analyzed for the heavy metals with atomic absorption spectrophotometer (GBC 902). Standard laboratory techniques were used to determine the organiccarbon by Walkey Black wet oxidation method [23], Total Kjeldahl Nitrogen (Macro-Kjeldahl method) [24], and potassium content (using sodium tetraphenylboron volumetric method as described by Motsara and Roy [25]. The data collected were subjected to statistical analysis of variance and significant differences among the treatment means were evaluated using Duncan's Multiple Range Test (DMRT) at $5 \%$ probability level.

\section{Results}

Tables 1-4 show the results obtained from the chemical analyses of compost samples from different recipes. From the Table 1, BB appeared (to be- remove) the best recipe for the following elements: $\mathrm{C}$

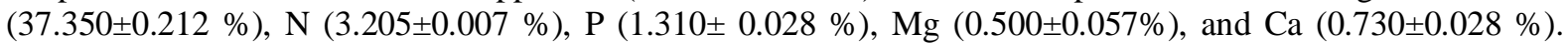


Evaluation of Fluted Pumpkin (Telfairia occidentalis Hookf.) Waste as Nutrient Amendment in

Addition of MMW to Telfairia occidentalis waste before composting reduced the concentrations of $\mathrm{N}$ and $\mathrm{P}$ in the compost produced against when it was mixed with CIW alone. Also, P and C in TO compost with Telfairia occidentalis alone $(0.900 \pm 0.057$ and $34.950 \pm 0.495 \%)$ were more than what found in CC compost with the mixture of MMW and CIW $(0.195 \pm 0.021$ and $33.650 \pm 0.212 \%)$ respectively. However, $\mathrm{K}$ in the TO compost $(1.785 \pm 0.064 \%)$ was lower than what found in the CC compost $(1.865 \pm 0.021 \%)$ though (remove,) the difference was not significant $(\mathrm{P}>0.05)$. The same condition applied to $\mathrm{S}$ which was found lower in $\mathrm{BB}$ $(0.305 \pm 0.035 \%)$ and TO $(0.335 \pm 0.035 \%)$ composts that contained Telfairia occidentalis waste against the CC $(0.455 \pm 0.021 \%)$ compost which was the control. The results of Duncan's Multiple Range Test (DMRT) at $5 \%$ probability level showed significant difference of nutrient composition $(\mathrm{P}<0.05)$ in virtually all the compost samples analysed (Table 3). However, there was exception in the following cases: C (AA Vs BB); N (BB Vs $\mathrm{CC}$ ); K (TO Vs CC); and Mg (TO Vs AA and BB Vs CC) where the difference was not significant (P>0.05).

Table 3 shows the variation in heavy metal contents of the compost samples. The levels of $\mathrm{Fe}, \mathrm{Pb}, \mathrm{Cd}$, and $\mathrm{Ni}$ in $\mathrm{AA}(271.500 \pm 9.192 \mathrm{mg} / \mathrm{kg}, 23.350 \pm 0.212 \mathrm{mg} / \mathrm{kg}, 7.200 \pm 7.920 \mathrm{mg} / \mathrm{kg}$ and $9.350 \pm 0.212 \mathrm{mg} / \mathrm{kg})$ respectively were significantly higher than in BB $(232.100 \pm 4.243 \mathrm{mg} / \mathrm{kg}, 21.750 \pm 0.212 \mathrm{mg} / \mathrm{kg}, 2.400 \pm 0.141$ $\mathrm{mg} / \mathrm{kg}, 9.050 \pm 0.354 \mathrm{mg} / \mathrm{kg})$ respectively. With exception to Ni that was highest in CC $(9.400 \pm 0.424 \mathrm{mg} / \mathrm{kg})$, all metals were found highest in AA and the differences were significant $(\mathrm{P}<0.05)$ as shown in Table 4. On the other hand, levels of $\mathrm{Zn}(694.450 \pm 0.354 \mathrm{mg} / \mathrm{kg})$ and $\mathrm{Cr}(26.000 \pm 0.141 \mathrm{mg} / \mathrm{kg})$ were greater in BB than AA $(687.400 \pm 1.556 \mathrm{mg} / \mathrm{kg}$ and $25.400 \pm 0.283 \mathrm{mg} / \mathrm{kg})$ respectively. The difference was not significant in case of $\mathrm{Cr}$ $(\mathrm{P}>0.05)$. In addition, $\mathrm{Zn}, \mathrm{Cd}, \mathrm{Pb}, \mathrm{Ni}, \mathrm{Fe}$ and $\mathrm{Cr}(626.750 \pm 2.192 \mathrm{mg} / \mathrm{kg}, 1.400 \pm 0.141 \mathrm{mg} / \mathrm{kg}, 19.300 \pm 0.283$ $\mathrm{mg} / \mathrm{kg}, 8.300 \pm 0.283 \mathrm{mg} / \mathrm{kg}, 220.500 \pm 7.778 \mathrm{mg} / \mathrm{kg}$ and $23.450 \pm 0.354 \mathrm{mg} / \mathrm{kg}$ ) respectively were lower in $\mathrm{TO}$ compare to CC $(681.350 \pm 0.212 \mathrm{mg} / \mathrm{kg}, 2.550 \pm 0.212 \mathrm{mg} / \mathrm{kg}, 20.600 \pm 0.141 \mathrm{mg} / \mathrm{kg}, 9.400 \pm 0.424 \mathrm{mg} / \mathrm{kg}$, $223.500 \pm 3.536 \mathrm{mg} / \mathrm{kg}$ and $26.400 \pm 0.141 \mathrm{mg} / \mathrm{kg}$ ) respectively. The difference was not significant in $\mathrm{Fe}(\mathrm{P}>0.05)$. This showed that higher levels of heavy metal were contained in CIW and MMW than Telfairia occidentalis waste.

\begin{tabular}{|c|c|c|c|c|}
\hline Var & s Samples & $\begin{array}{l}\text { Mean } \pm \text { Standard } \\
\text { Deviation }(\%, \text { dry } \\
\text { weight) }\end{array}$ & $F$ value & $P$ value \\
\hline $\mathbf{C}$ & $\begin{array}{l}\text { TO } \\
\text { AA } \\
\text { BB } \\
\text { CC } \\
\end{array}$ & $\begin{array}{l}34.950 \pm 0.495 \\
36.550 \pm 0.354 \\
37.350 \pm 0.212 \\
33.650 \pm 0.212\end{array}$ & 47.464 & 0.001 \\
\hline $\mathbf{N}$ & $\begin{array}{l}\text { TO } \\
\text { AA } \\
\text { BB } \\
\text { CC }\end{array}$ & $\begin{array}{l}3.110 \pm 0.000 \\
2.965 \pm 0.007 \\
3.205 \pm 0.007 \\
3.195 \pm 0.007 \\
\end{array}$ & $657 . .222$ & 0.000 \\
\hline $\mathbf{P}$ & $\begin{array}{l}\text { TO } \\
\text { AA } \\
\text { BB } \\
\text { CC }\end{array}$ & $\begin{array}{l}0.900 \pm 0.057 \\
1.070 \pm 0.014 \\
1.310 \pm 0.028 \\
0.195 \pm 0.021 \\
\end{array}$ & 53.115 & 0.001 \\
\hline $\mathbf{K}$ & $\begin{array}{l}\text { TO } \\
\text { AA } \\
\text { BB } \\
\text { CC } \\
\end{array}$ & $\begin{array}{l}1.785 \pm 0.064 \\
2.125 \pm 0.035 \\
1.670 \pm 0.028 \\
1.865 \pm 0.021 \\
\end{array}$ & 43.468 & 0.002 \\
\hline Mg & $\begin{array}{l}\text { TO } \\
\text { AA } \\
\text { BB } \\
\text { CC }\end{array}$ & $\begin{array}{l}0.375 \pm 0.050 \\
0.300 \pm 0.028 \\
0.500 \pm 0.057 \\
0.510 \pm 0.028\end{array}$ & $11 . .372$ & 0.020 \\
\hline $\mathbf{S}$ & $\begin{array}{l}\text { TO } \\
\text { AA } \\
\text { BB } \\
\text { CC } \\
\end{array}$ & $\begin{array}{l}0.335 \pm 0.035 \\
0.430 \pm 0.113 \\
0.305 \pm 0.035 \\
0.455 \pm 0.021\end{array}$ & 2.670 & 0.183 \\
\hline Ca & $\begin{array}{l}\text { TO } \\
\text { AA } \\
\text { BB } \\
\text { CC } \\
\end{array}$ & $\begin{array}{l}0.600 \pm 0.028 \\
0.615 \pm 0.078 \\
0.730 \pm 0.028 \\
0.665 \pm 0.021 \\
\end{array}$ & $3 . .399$ & 0.134 \\
\hline
\end{tabular}

Table 1: Nutrient Characteristics of Compost Samples 
Evaluation of Fluted Pumpkin (Telfairia occidentalis Hookf.) Waste as Nutrient Amendment in

\begin{tabular}{|c|c|c|c|c|}
\hline \multicolumn{2}{|c|}{ Variables Vs Samples } & \multirow{2}{*}{$\begin{array}{l}\text { Mean } \pm \text { Standard } \\
\begin{array}{l}\text { Deviation }(\mathbf{m g} / \mathrm{kg}, \text { dry } \\
\text { weight) }\end{array} \\
220.500 \pm 7.778 \\
271.500 \pm 9.192 \\
232.100 \pm 4.243 \\
223.500 \pm 3.536\end{array}$} & \multirow{2}{*}{$\begin{array}{l}\text { Fvalue } \\
25.356\end{array}$} & \multirow{2}{*}{$\begin{array}{l}\text { Pvalue } \\
\\
0.005\end{array}$} \\
\hline $\mathrm{Fe}$ & $\begin{array}{l}\text { TO } \\
\text { AA } \\
\text { BB } \\
\text { CC }\end{array}$ & & & \\
\hline $\mathrm{Pb}$ & $\begin{array}{l}\text { TO } \\
\text { AA } \\
\text { BB } \\
\text { CC }\end{array}$ & $\begin{array}{l}19.300 \pm 0.283 \\
23.350 \pm 0.212 \\
21.750 \pm 0.212 \\
20.600 \pm 0.141\end{array}$ & 124.702 & 0.000 \\
\hline Cd & $\begin{array}{l}\text { TO } \\
\text { AA } \\
\text { BB } \\
\text { CC }\end{array}$ & $\begin{array}{l}1.400 \pm 0.141 \\
7.200 \pm 7.920 \\
2.400 \pm 0.141 \\
2.550 \pm 0.212\end{array}$ & 0.856 & 0.532 \\
\hline Zn & $\begin{array}{l}\text { TO } \\
\text { AA } \\
\text { BB } \\
\text { CC } \\
\end{array}$ & $\begin{array}{l}626.750 \pm 2.192 \\
687.400 \pm 1.556 \\
694.450 \pm 0.354 \\
681.350 \pm 0.212\end{array}$ & 1036.808 & 0.000 \\
\hline $\mathbf{N i}$ & $\begin{array}{l}\text { TO } \\
\text { AA } \\
\text { BB } \\
\text { CC }\end{array}$ & $\begin{array}{l}8.300 \pm 0.283 \\
9.350 \pm 0.212 \\
9.050 \pm 0.354 \\
9.400 \pm 0.424\end{array}$ & 4.791 & 0.082 \\
\hline $\mathrm{Cr}$ & $\begin{array}{l}\text { TO } \\
\text { AA } \\
\text { BB } \\
\text { CC } \\
\end{array}$ & $\begin{array}{l}23.450 \pm 0.354 \\
25.400 \pm 0.283 \\
26.000 \pm 0.141 \\
26.400 \pm 0.141 \\
\end{array}$ & 55.857 & 0.001 \\
\hline
\end{tabular}

Table 2: Heavy Metal Contents of Compost Samples

\begin{tabular}{|c|c|c|c|c|c|}
\hline $\begin{array}{l}\text { Dependent } \\
\text { Variable }\end{array}$ & I Group & J Group & Mean Difference (I-J) (\%) & Std. Error & $P$ value \\
\hline \multirow{6}{*}{ C } & \multirow[t]{3}{*}{ TO } & $\mathbf{A A}$ & $-1.600 *$ & 0.339 & 0.009 \\
\hline & & BB & $-2.400^{*}$ & 0.339 & 0.002 \\
\hline & & $\mathrm{CC}$ & $1.300 *$ & 0.339 & 0.019 \\
\hline & \multirow[t]{2}{*}{ AA } & BB & -0.800 & 0.339 & 0.078 \\
\hline & & $\mathrm{CC}$ & $2.900 *$ & 0.339 & 0.001 \\
\hline & BB & $\mathbf{C C}$ & $3.700 *$ & 0.339 & 0.000 \\
\hline \multirow{6}{*}{$\mathbf{N}$} & \multirow[t]{3}{*}{ TO } & $\overline{\mathbf{A A}}$ & $0.145^{*}$ & 0.006 & 0.000 \\
\hline & & BB & $-0.095^{*}$ & 0.006 & 0.000 \\
\hline & & $\mathrm{CC}$ & $-0.085^{*}$ & 0.006 & 0.000 \\
\hline & \multirow[t]{2}{*}{$\overline{\mathbf{A A}}$} & BB & $-0.240 *$ & 0.178 & 0.000 \\
\hline & & $\mathrm{CC}$ & $-0.230 *$ & 0.006 & 0.000 \\
\hline & BB & $\mathrm{CC}$ & 0.010 & 0.006 & 0.178 \\
\hline \multirow{6}{*}{$\mathbf{P}$} & \multirow[t]{3}{*}{ TO } & $\mathbf{A A}$ & $-0.170 *$ & 0.034 & 0.008 \\
\hline & & BB & $-0.410 *$ & 0.034 & 0.000 \\
\hline & & $\mathrm{CC}$ & $-0.295^{*}$ & 0.034 & 0.001 \\
\hline & \multirow[t]{2}{*}{$\overline{\mathbf{A A}}$} & BB & $-0.240 *$ & 0.034 & 0.002 \\
\hline & & $\mathrm{CC}$ & $-0.125^{*}$ & 0.034 & 0.021 \\
\hline & BB & $\mathrm{CC}$ & $0.115^{*}$ & 0.034 & 0.028 \\
\hline \multirow{6}{*}{$\mathbf{K}$} & \multirow[t]{3}{*}{ TO } & $\mathbf{A A}$ & $-0.330^{*}$ & 0.040 & 0.001 \\
\hline & & BB & $0.115^{*}$ & 0.040 & 0.047 \\
\hline & & $\mathrm{CC}$ & -0.080 & 0.040 & 0.119 \\
\hline & \multirow[t]{2}{*}{$\overline{\mathbf{A A}}$} & BB & $0.445^{*}$ & 0.040 & 0.000 \\
\hline & & $\mathrm{CC}$ & $0.250 *$ & 0.040 & 0.003 \\
\hline & BB & $\mathrm{CC}$ & $-0.195 *$ & 0.040 & 0.009 \\
\hline \multirow{6}{*}{ Mg } & \multirow[t]{3}{*}{ TO } & $\mathbf{A A}$ & 0.075 & 0.043 & 0.153 \\
\hline & & BB & $-0.125^{*}$ & 0.043 & 0.043 \\
\hline & & $\mathrm{CC}$ & $-0.135^{*}$ & 0.043 & 0.034 \\
\hline & \multirow[t]{2}{*}{ AA } & BB & $-0.200 *$ & 0.043 & 0.009 \\
\hline & & $\mathrm{CC}$ & $-0.210^{*}$ & 0.043 & 0.008 \\
\hline & BB & $\mathrm{CC}$ & -0.010 & 0.043 & 0.826 \\
\hline
\end{tabular}

Table 3: Multiple Comparisons for Nutrient Mean Values of Compost Samples

* The mean difference is significant at the 0.05 significant level $(\mathbf{P}<0.05)$. 
Evaluation of Fluted Pumpkin (Telfairia occidentalis Hookf.) Waste as Nutrient Amendment in

Table 4: Multiple Comparisons for Selected Heavy Metal Mean Values of Compost Samples

\begin{tabular}{|c|c|c|c|c|c|}
\hline $\begin{array}{l}\text { Dependent } \\
\text { Variable }\end{array}$ & I Group & J Group & $\begin{array}{l}\text { Mean Difference (I-J) } \\
(\mathrm{mg} / \mathrm{kg})\end{array}$ & Std. Error & $P$ value \\
\hline \multirow{6}{*}{$\mathbf{F e}$} & \multirow{3}{*}{ TO } & $\mathbf{A A}$ & $-51.000 *$ & 6.624 & 0.002 \\
\hline & & BB & -11.600 & 6.624 & 0.155 \\
\hline & & $\mathrm{CC}$ & -3.000 & 6.624 & 0.674 \\
\hline & \multirow{2}{*}{$\overline{\mathbf{A A}}$} & BB & $39.400 *$ & 6.624 & 0.004 \\
\hline & & $\mathrm{CC}$ & $48.000^{*}$ & 6.624 & 0.002 \\
\hline & BB & $\mathrm{CC}$ & 8.600 & 6.624 & 0.264 \\
\hline \multirow{6}{*}{$\mathbf{P b}$} & \multirow[t]{3}{*}{ TO } & $\mathbf{A A}$ & $-4.050^{*}$ & 0.218 & 0.000 \\
\hline & & BB & $-2.450 *$ & 0.218 & 0.000 \\
\hline & & $\mathrm{CC}$ & $-1.300 *$ & 0.218 & 0.004 \\
\hline & \multirow{2}{*}{$\overline{\mathbf{A A}}$} & BB & $1.600^{*}$ & 0.218 & 0.002 \\
\hline & & $\mathrm{CC}$ & $1.150^{*}$ & 0.218 & 0.000 \\
\hline & BB & $\mathrm{CC}$ & $2.750 *$ & 0.218 & 0.006 \\
\hline \multirow{6}{*}{$\mathbf{Z n}$} & \multirow[t]{3}{*}{ TO } & $\mathbf{A A}$ & $-60.650^{*}$ & 1.360 & 0.000 \\
\hline & & BB & $-67.700^{*}$ & 1.360 & 0.000 \\
\hline & & $\mathrm{CC}$ & $-54.600 *$ & 1.360 & 0.000 \\
\hline & \multirow[t]{2}{*}{$\mathbf{A A}$} & BB & $-7.050 *$ & 1.360 & 0.007 \\
\hline & & $\mathrm{CC}$ & $6.050 *$ & 1.360 & 0.011 \\
\hline & BB & $\mathrm{CC}$ & $13.100^{*}$ & 1.360 & 0.001 \\
\hline \multirow{6}{*}{$\mathrm{Cr}$} & \multirow[t]{3}{*}{ TO } & $\mathbf{A A}$ & $-1.950 *$ & 0.247 & 0.001 \\
\hline & & BB & $-2.550^{*}$ & 0.247 & 0.001 \\
\hline & & $\mathrm{CC}$ & $-2.950 *$ & 0.247 & 0.000 \\
\hline & \multirow[t]{2}{*}{$\mathbf{A A}$} & BB & -0.600 & 0.247 & 0.072 \\
\hline & & $\mathrm{CC}$ & $-1.000 *$ & 0.247 & 0.016 \\
\hline & BB & $\mathrm{CC}$ & -0.400 & 0.247 & 0.181 \\
\hline
\end{tabular}

* The mean difference is significant at the 0.05 significant level $(\mathrm{P}<0.05)$.

\section{Discussions}

The nitrogen content of Telfairia occidentalis composts was higher compare to nutrient contents in California composts with total nitrogen of 1.0-2.0\% [26]. Higher nitrogen content corroborated with higher percentage of crude protein $(35.14 \pm 0.44 \%)$ found in Telfairia occidentalis leaf meal [16]. The values obtained for $\mathrm{N}, \mathrm{Ca}, \mathrm{K}$ and $\mathrm{Mg}$ by these researchers were higher than the values obtained in this study. This was probably due to different methods involved in processing the meal and compost. However, P value was similar in both studies. The nutrient values of compost made from Telfairia occidentalis waste and CIW, that is BB recipe, are in consonance with the standards established by National Special Programme on Food Security [27]. The standards includes, total organic carbon (At least 20\%); nitrogen (1.0 to 4.0\%); phosphorus (1.5 to 3.0\%); and potassium (1.0 to $1.5 \%)$. They also meet the primary characteristics of organic fertilizer under specification of the Land Development Department in Thailand [28] which stated the following: organic C, $>17.4 \%$; organic N, $>2.00 \%$; total $\mathrm{P},>0.440 \%$; and, $\mathrm{K},>0.830 \%$. Approximately $20 \%$ of phosphorus in compost react like $\mathrm{P}$ in mineral fertilizers and are immediately available for plant uptake while the remainder is more strongly bound and will become available later. Virtually all potassium supplied with compost can be used immediately by plants while $40 \%$ of all nitrogen contained in compost at the time of application will become available to plants [29].

The levels of some heavy metals like $\mathrm{Pb}, \mathrm{Ni}$, and $\mathrm{Cr}$ in the compost made from $\mathrm{BB}$ recipe that was adjudged the best are in agreement with maximum recommended limit [30]. Its $\mathrm{Cd}$ content was lower than German standard [31]. Zn concentration was higher than the levels specified in both standards but lower than what obtained in a similar study [16]. Meanwhile, survey had earlier been carried out which aimed at identifying a technological solution for reducing heavy metal contents in the compost with a particular reference to $\mathrm{Zn}$ and $\mathrm{Pb}$ [32]. The study concluded that by eliminating a fraction of compost $<1 \mathrm{~mm}$, both $\mathrm{Zn}$ and $\mathrm{Pb}$, could be removed, without a substantial yield loss. Only $10 \%$ of the final product would be eliminated. Also, $\mathrm{Pb}$ and $\mathrm{Ni}$ levels were found lower than the maximum limit of compost in Denmark [33]. The Canadian Council of Ministers of the Environment Guidelines for Compost Quality was based on the following four criteria for product safety and quality: foreign matter, maturity, pathogens, and trace elements [34]. The levels specified for the trace elements in $\mathrm{mg} / \mathrm{kg}(\mathrm{Pb}, 150 ; \mathrm{Cd}, 3 ; \mathrm{Ni}, 62 ; \mathrm{Zn}, 700$; and, $\mathrm{Cr}, 210)$ were higher than what obtained in this studies for BB. Surprisingly, the levels of heavy metals analyzed in the leaves of Telfairia occidentalis [35] were very far below those found in its compost from this study. The reason was that compost has binding site 
for heavy metals. This mechanism immobilizes these harmful elements in the soil and makes them unavailable to plants.

\section{Conclusion}

The study showed that Telfairia occidentalis waste has potential for improving compost nutrient quality. Combination of Telfairia occidentalis waste and Cow Intestinal Waste appeared to be the best recipe for Telfairia occidentalis waste management through composting. It gave higher levels of macro nutrients like Nitrogen, phosphorus, calcium, carbon, magnesium and micronutrients that are required by plants. Telfairia occidentalis waste also contained lower levels of heavy metals, making is suitable for composting. It can be used as an alternative source of nutrient amendment of compost. Hence, the management of Telfairia occidentalis waste through composting serves dual purposes of recovering nutrients locked-up in the stalk and leaves for plant growth and environmental sanitation. It is recommended that more researches should be carried out to evaluate composting potentials of pumpkin seeds and perhaps fruit kernel that can also pose serious environmental problem for their poor management.

\section{References}

[1] S.N. Asoegwu, Effects of irrigation on the leaf and pod production of fluted pumpkin (Telfairia occidentalis Hook. f.) in Southern Nigeria, Food Chemistry, 70(2), 2000, 235-240.

[2] M.O. Balogun, S.R Ajibade, and B.A Ogunbodede, Micropropagation of Fluted Pumpkin by enhanced axillary shoot formation, Nig. J. Hortic. Sci. $6(1), 2002,85-88$.

[3] S.A. Ajayi, M.E. Dulloo, R.S. Vodouhe, P. Berjak, and J. I. Kioko, Conservation status of Telfairia spp in sub-Saharan Africa. Paper presented at the Regional workshop on Plant Genetic Resources and food security in West and Central Africa, held at IIT A, Ibadan, April 26-30, 2004.

[4] J.T. Opabode, and O.C. Adebooye, Application of biotechnology for the improvement of Nigerian indigenous leaf vegetables. African Journal of Biotechnology, 4 (2), 2005, 138-142.

[5] W.B. Akanbi, T.A Adebayo, O.A Togun, A.S. Adeyeye, and O. A. Olaniran, The Use of Compost Extract as Foliar Spray Nutrient Source and Botanical Insecticide in Telfairia occidentalis, World Journal of Agricultural Sciences 3 (5), 2007, 642-652.

[6] J.E Ehiagbonare, Conservation studies on Telfairia occidentalis Hook .F. A. indigenous plant used in enthnomedicinal treatment of anemia in Nigeria, African Journal of Agricultural Research 3 (1), 2008, 074-077.

[7] M.O. Akoroda, Seed production and breeding potential of the fluted pumpkin, Telfairia occidentalis, Euphotic. 49 (1), $1990,25-32$.

[8] N. I. Odiaka and R.R. Schippers, Telfairia occidentalis Hook.f, in G.J.H. Grubben and O.A. Denton (Editors), Plant Res. Trop. Afr. 2:Vegetables, (PROTA Foundation, Netherlands/Backhuys Publishers: Leiden, Netherlands/CTA Wageningen, Netherlands, 2004) 522-527.

[9] G.I.O. Badifu, and A.O. Ogunsua, Chemical composition of kernels from some species of cucurbitacea grown in Nigeria, Plant Food Human Nutr., 41, 1991, 35-44.

[10] A.A. Mohammed, Chemical composition and oil characteristics of pumpkin (cucurbitamaxima) seed kernels, Food Sci. \& Agric Res. No. (129), 2004, 518.

[11] E.I. Nwanguma, J. A. Akinfasoye, B.R Aminu-Taiwo, and W.B Akanbi, Effectiveness of intercropping and staking in the management of root-knot nematode for rural farmers in intensive mixed vegetable cropping systems in South-western Nigeria, International Journal of Organic Agriculture Research and Development 1 (1), 2010, 25-36.

[12] B.N. Okigbo, Neglected plants of horticultural and nutritional importance in traditional farming systems of tropical Africa, Acta Horticult, 53, 1977, 131-150.

[13] J.C. Okafor, Horticulturally promising indigenous wild plant species of the Nigerian forest zone, Acta Horticult. 123, 1983, 165176.

[14] O.C Adebooye, F.M.D. Ogbe, and J.F. Bamidele, Ethnobotany of indigenous leaf vegetables of southwest Nigeria, Delpinoa, Italy, Vol. 45, 2003, 295-299.

[15] U.A. Ekpedeme, A.N. Bassey, and U.E Ekaete, Minerals and antinutrients in fluted pumpkin (Telfairia occidentalis Hookf.) Food Chemistry, $70(2,1), 2000,235$.

[16] A.O Fasuyi,. and A.D. Nonyerem, Biochemical, nutritional and haematological implications of Telfairia occidentalis leaf meal as protein supplement in broiler starter diets, African Journal of Biotechnology, 6 (8), 2007, 1055-1063.

[17] H.D. Tindal, Vegetables in the Tropics (Macmillan Education Ltd.:Houndmills, Hampshire, 1986) 533.

[18] Z.O Gbile, Ethnobotany, taxonomy and conservation of Medicinal plants in A. Sofowora (ed), "The state of Medicinal plant Research" (University of Ibadan Press: Nigeria, 1986) 13-29.

[19] M. A. Weiner, Earth Medicine (Macmillian: New York, 1992) 12.

[20] S.A Ajayi, P. Berjak, J.I. Kioko, M E. Dulloo, and R.S. Vodouhe, Responses of fluted pumpkin (Telfairia occidentalis Hook. f.; Cucurbitaceae) seeds to desiccation, chilling and hydrated storage, South African Journal of Botany 72(4), 2006, 544-550.

[21] T.B Hammed, A.A. Soyingbe, and D.O. Adewole, An Abattoir Waste Water Management through Composting: A Case Study of Alesinloye Waste Recycling Complex, The international journal of interdisciplinary social sciences, 6 (2), $2011,67-78$.

[22] T.B. Hammed, M.K.C. Sridhar, I.O. Olaseha, E.O. Oloruntoba, and G.R.E.E. Ana, Integrating a State Owned Waste Recycling Facility and Neighbourhood Participation for Sustainable Management, The international journal of interdisciplinary social sciences 6 (8), 2012, 11-24.

[23] A. Walkley, and I.A. Black, Method of total organic carbon determination in soil samples, Soil Science, 37, 1934, 29-38.

[24] M. L. Jackson, Soil chemical analysis (Englewood Cliffs, N. J.: Prentice Hall, 1963).

[25] M. R. Motsara and R. N Roy, Guide to laboratory establishment for plant nutrient analysis. Food and Agriculture Organization of the United Nations (FAO) Fertilizer and Plant Nutrition Bulletin, 19, 2008, 101-103.

[26] California Department of Resources Recycling and Recovery (c 1995- 2010), Quality Standards for Finished Compost, (updated: March 18, 2004). Available at http://www.calrecycle.ca.gov/Organics/

[27] National Special Programme on Food Security, National Minimum Quality Standards for Compost, Nigeria, 2007.

[28] The Land Development Department, Plant, Fertilizer, Water and Soil Analysis Manual (Ministry of Agriculture and Cooperatives: Bangkok, Thailand, 2005) 254. 
[29] B. Johannes, The Use of Recycled Organics Compost in Viticulture: A review of the international literature and experience, in $\mathrm{H}$. Willer and U. Meier, (eds.), Proceedings of the 6th International Congress on Organic Viticultre, Basel, Switzerland, 2000, 130134.

[30] BodSch, Bundes-Bodenschutzverordnung. (Federal Soil Protection Rule) in Bodenschutz (Soil Protection) (Erich Schmidt Verlag: Berlin, 1998).

[31] P. Kraus and U. Grammel, Relevant of contaminant discussion for bio-waste composting, Abfallwirtschaft, 9, 1992, 65-85.

[32] Z.Mariachiara, C.Fabrizio, F Daniele, F Franco, and P. Bruno, Heavy metal contamination in compost: a possible solution, Annali di Chimica, 95 (3-4), 2005, $247-256$.

[33] L. Nielsen, and I. Küger, Contents of heavy metals in compost from source separated waste in Denmark - examination of sampling reliability ISHS Acta Horticulturae. unknown date, 302.

[34] Guidelines for Compost Quality, Canadian Council of Ministers of the Environment. (Winnipeg, Manitoba R3. C 1 A3, c2005) 1-26.

[35] A.A. Yusuff, S. Adewuyi and A.A. Lasis, Physic-chemical composition of leaves, meals and oils of fluted pumpkin (Telfairia occidentalis) and melon (citrillus vulgaris), Agricultural Journal 1 (1), 2006, 32-35. 